\title{
Comparitive Study of Heavy metals accumulation by Plants belongs to Amaranthaceae family
}

\author{
Neetha Jose \\ Department of Botany, Sree Narayana College, Kannur-6700071
}

\begin{abstract}
This study investigated the accumulation of heavy metals like $\mathrm{As}, \mathrm{Pb}$, and $\mathrm{Cd}$ by plants belongs to family Amaranthaceae and soil occurred around the polluted area of Thrissur District. Plants from involved in this studies were Hygrophila angustifolia and Alternanthera tenella,.The concentration of metals in root, shoot and leaf were varies across the plant species and the plant parts. The observed metallic levels in plants were not within the FAO/WHO limit guideline values for heavy metal levels in food. But in soil, heavy metal content was within the permissible limits recommanded by World Health Organization (WHO).
\end{abstract}

Key words:- Heavy metals, As,Pb, Cd, Hygrophila angustifolia, Alternanthera tenella, , FAO/WHO

\section{INTRODUCTION}

Now a days heavy metal contamination in plants has a serious burning issue in this world. Urbanization and industrialization are one of the major causes of heavy metal accumulation in plants. Inappropriate discharge of industrial effluents leads to the accumulation of heavy metals in the surrounding area of the industrial site. Several naturally occurring and growing plant species located in these surrounding area of the industrial site. These plants absorb nutients from this metal enriched soil. Through food chain, it enters into humans and animals and it is severely toxic to the health. Consumption of these plants as a vegetable or medicine, these toxic metals reaches human diet and it creates numerous health problem and disorders.

Toxic metals are mainly $\mathrm{As}, \mathrm{Cd}$ and $\mathrm{Pb}$. They are non-essential heavy metals, which are not needed by living organisms for any physiological functions . (Mertz, Suzuki and Sano, 2001) Chronic exposure to Lead results in birth defects, mental retardation and potential toxic effects on fetus. Elevated levels of cadmium and chromium are responsible for lung, renal and cardiovascular diseases.

The investigation has revealed that soil and native plant samples predominantly contaminated with As, $\mathrm{Cd}$ and $\mathrm{Pb}$ in the surrounding area of industry located at Thrissur. The distribution of the heavy metals in the plants grown on the industrially contaminated soil differed from plant to plant. Based on the FAO/WHO limit guideline values for heavy metal levels in food, most edible parts of these plants from the study areas are heavily polluted with the heavy metals.

\section{MATERIALS \& METHODS}

Study Area: The present study was carried out in the industrial area of Thrissur, to analyse the concentration of heavy metals in native plant species and soil samples. It is located in $38 \mathrm{~km}$ south of Thrissur.

Sampling: Plant species were collected from this site. The plants were carefully dug from the substrate and most of the bulk soil was manually removed from the roots. At least five individual plants from each species were collected and labelled. Plant species were identified by expert taxonomists. In total, 2 plant samples belonging to same families were collected (Table 1).

Prior to the analysis of plant material, shoots, leaves and roots of the plants were separated and carefully washed with tap water in order to remove any surface soil or dust deposits. After washing, samples were air dried at room temperature and fresh weights of plants were measured. Then plant samples were oven dried at $65^{\circ} \mathrm{C}$ till constant weight and dry weight of plants were also measured. The dried plant materials were ground into fine powder for further analysis.(Indian standard methods of sampling and test, 1999).

\section{RESULTS}

The present study was carried out the observation of the native plant species in the study site and screening of commonly occuring native species. The results are given below. 
Vol. 8, Issue 12, December 2021

DOI: $10.17148 /$ IARJSET.2021.81221

Table 1. Plant species identified and used in the study from th e industrial site

\begin{tabular}{|l|l|l|l|l|}
\hline No: & Name of species & Family & Habit & \\
\hline 1 & Hygrophilla auriculata & Amaranthaceae & Herb & Angiosperm Dicot \\
\hline 2 & Alternanthera tenella & Amaranthaceae & Annual herb & Angiosperm Dicot \\
\hline
\end{tabular}

Table -2 Maximum permissible limits of heavy metals in plants ( $\mu$ gg-1) has been established by standard regulatory bodies such as by World Health Organization (WHO) as shown in Table 2 below

\begin{tabular}{|l|l|}
\hline Heavy metal & $\begin{array}{l}\text { Maximum permissible level in Plant } \\
(\mu g g-1)\end{array}$ \\
\hline As & - \\
\hline Cd & 0.10 \\
\hline Pb & 0.30 \\
\hline
\end{tabular}

Table- 3 Mean heavy metal concentrations ( $\mu g g-1$ dry weight) in Hygrophila angustifolia from study area .

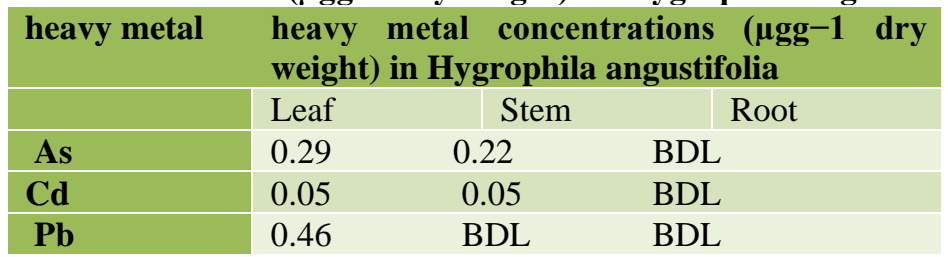

Table- 4 Mean heavy metal concentrations ( $\mu g g-1$ dry weight) in Alternanthera tenella

\begin{tabular}{|c|c|c|c|c|}
\hline & \multicolumn{4}{|c|}{$\begin{array}{l}\text { heavy metal concentrations ( } \mu g g-1 \text { dry } \\
\text { weight) in Alternanthera tenella }\end{array}$} \\
\hline & Leaf & Stem & & Root \\
\hline As & 0.19 & 0.09 & 0.37 & \\
\hline Cd & BDL & 0.24 & 0.46 & \\
\hline $\mathbf{P b}$ & 0.75 & 0.75 & 1.72 & \\
\hline
\end{tabular}

\section{DISCUSSION}

From the field, 2 native herb species were collected .They belonging to same families including Amaranthaceae, (Table 1). Metal accumulation in plant tissues was evaluated from most abundant species growing around the industry

There were significant difference shown in $\mathrm{As}, \mathrm{Cd}$ and $\mathrm{Pb}$ accumulation in plant species and soil. In plants, Arsenic concentration ranges from non-detectable to $0.37 \mu \mathrm{gg}-1$. But in the case of Cadmium, it ranges from non-detectable to $0.46 \mu \mathrm{gg}-1$ and concentration of lead ranges from non-detectable to $1.72 \mu \mathrm{gg}-1$ (Table 3-4). The concentration of metals in root, shoot and leaf were varies across the plant species and the plant parts.

In Punjab, analysis of garlic contained relatively higher levels of toxic heavy metals like Pb and Cd.So (Ata et al., 2013). The increasing level of metals in plants showed that the plants are grown in contaminated area.

The metal content in $\mathrm{H}$. angustifolia samples was observed to be decreasing order as $\mathrm{As}>\mathrm{Pb}>\mathrm{Cd}$. But in $\mathrm{A}$. tenella decreased according to the sequence: $\quad \mathrm{Pb}>\mathrm{Cd}>\mathrm{As}$. The concentration of $\mathrm{As}, \mathrm{Cd}$ and $\mathrm{Pb}$ present in the two plant species were very high compared to the WHO limit guideline values for heavy metal levels in food. (Table 2 -6).

Heavy metals in plants and soil beyond WHO guidelines, are dangerous because it interfere with the body functions.So continuous checking of metal enriched areas of soil and native plants is needed to prevent the metal toxic effect on the human and animals.

Naturally heavy metals are absent in plants. But in this case, it may be due to the influence of industrial effluents especially toxic heavy metals that have settled on the soil.

\section{CONCLUSION}

The investigation has revealed that and native plant samples predominantly contaminated with $\mathrm{As}, \mathrm{Cd}$ and $\mathrm{Pb}$. It implies that the Plants growing around the industrial area is not safe for human consumption because of toxic metal deposition in its tissues. This is the first report to access the toxic heavy metal in plant samples, collected from industrial area in Trissur. So in further studies concern about all flora of the region such as grasses, herbs and shrubs in the industrial areas needs proper attention. 
International Advanced Research Journal in Science, Engineering and Technology

Vol. 8, Issue 12, December 2021

DOI: 10.17148/IARJSET.2021.81221

REFERENCES

Ewers, U .Standards, Guidelines and Legislature Regulations Concerning Metals and Their Compounds. In: Metals and Their Compounds in Environment Merian. E. (Ed), VCH,Weinheim, New York, Basel, Cambridge, 199, 1687 -711.

Indian standard methods of sampling and test (Physical \&Chemical ) for water and waste water part-1 Sampling (first revision ) Ist revision) Is 3025 (Part1)-1987 (Reaffirmed 1998)edition 2.1(1999-12)

Mertz, W.1981. The essential trace elements Science 213:1332-1338.

World Health Organization (WHO). Quality Control methods for medicinal plant materials. Geneva W HO. 1998 